Journal of Bangladesh College of Physicians and Surgeons

Vol. 28, No. 3, September 2010

\title{
Pregnancy with Idiopathic Thrombocytopenic Purpura - A Case Report
}

\author{
R AKTHER ${ }^{\mathrm{a}}$, T HOSSAIN ${ }^{\mathrm{b}}$, MA KHAN ${ }^{\mathrm{c}}$, MALIHA RASHID ${ }^{\mathrm{d}}$
}

\begin{abstract}
Summary:
Thrombocytopenia in pregnancy has many common causes, including gestational thrombocytopenia, viral and bacterial infections, and preeclampsia complicated by hemolysis, elevated liver enzymes, and low platelet (HELLP) syndrome. The great concern for ITP during pregnancy is the risk of thrombocytopenia in the newborn infant. A 30yrs old 3rd gravid women was admitted in maternity unit 3, Dhaka Medical College Hospital with the complaints of 36weeks pregnancy, lower abdominal pain and less fetal movement. She had been suffering from severe thrombocytopenia for
\end{abstract}

\section{Introduction:}

Thrombocytopenia is a common diagnostic \& management issue during pregnancy ${ }^{1}$.Asymptomatic thrombocytopenia occurs near term or peripartum period in about $5 \%$ normal pregnancies.The reference range of a normal platelet count in non pregnant women and newborns is $150,000-400,000 / \mu \mathrm{L}$.However, platelet counts during pregnancy are normal in most ${ }^{2}$ women. Thrombocytopenia in pregnancy has many common causes, including gestational thrombocytopenia, viral and bacterial infections, and pre-eclampsia complicated by hemolysis, elevated liver enzymes, and low platelet (HELLP syndrome) count. This article focuses on the gestational thrombocytopenia, immune thrombocytopenic purpura (ITP) and neonatal alloimmune thrombocytopenia

a. Dr. Rabeya Akther, FCPS, Bangladesh Bank Medical Center, Dhaka, Bangladesh.

b. Dr. Taufiqua Hossain, FCPS, MS, Consultant, Dhaka Medical Collage\& Hospital, Dhaka.

c. Prof. Mohiuddin Ahmed Khan, FCPS, Professor, Department of Hematology, Dhaka Medical Collage\& Hospital, Dhaka, Bangladesh.

d. Prof. Maliha Rashid, FCPS, Professor, Department of Obstetrics and Gynecology, Dhaka Collage\& Hospital, Dhaka, Bangladesh.

Address of Correspondence: Dr. Rabeya Akther Fellow no: 1996(Obstetric \& Gynaecology), Senior Medical Officer, Bangladesh Bank Medical Center Motijheel, Dhaka, Bangladesh, Telephone: 8313533, 01817517100 (mobile), Email: rabeyrakther@yahoo.com Received: 13 May, 2008

Accepted: 20 September, 2010 the last 8 months. She treated with Prednisolone during pregnancy period, platelet transfusion before and after delivery and Danazol in puerperium. Her baby was delivered by caesarean section.Her intra-operative and post operative period was uneventful. She delivered a healthy male baby weighted $2.5 \mathrm{~kg}$ and breast feeding established successfully. She was discharged on seventh post operative day. The aim of this case report to reveal pregnancy with ITP and its clinical presentation, investigation and management with review of relevant literatures.

(J Bangladesh Coll Phys Surg 2010; 28: 196-198)

(NAIT) and its management during pregnancy, labor and puerperium. These relatively rare causes of thrombocytopenia are important, as neonatal outcomes can be significantly impaired and subsequent pregnancies can be affected. ${ }^{1}$

\section{Case Report:}

A 30yrs old lady became pregnant for 3 times and given birth thrice (G3 P3). Her $1^{\text {st }}$ two pregnancies were uncomplicated but $3^{\text {rd }}$ pregnancy complicated by severe thrombocytopenia. She was admitted to DMCH with the complaints of 36weeks pregnancy, lower abdominal pain and less fetal movement for three days. She has been suffering from ITP for the last 8 months. She was on regular antenatal care and jointly monitored by obstetrician and Hematologist at DMCH. Her total platelet count was within the range of 20,000-30,000 / $\mu \mathrm{L}$ of blood throughout the pregnancy. She was treated with Prednisone 20gm bid and Folic acid. It was her adjusted dose below this level she developed purpuric spot. She had no history of thrombocytopenia in previous pregnancy, menorrhagia, bleeding after circumcision or simple cut injury of her children.

Regarding her past history, she suddenly developed mild gum bleeding eight months back and her hematological examination revealed that bleeding time was $8.4 \mathrm{~min}$ and clotting time was $4.30 \mathrm{~min}$ and total platelet count was $30,000 / \mu \mathrm{L}$ of blood, her ANA 
antibody and Anti-ds DNA were negative. Bone marrow study showed that normal $\mathrm{M}$ : E ratio and Dysmegakaryopoises. She became pregnant during her lactational amenorrhoea period .Positive pregnancy test and sonography (11 wks 4 days) confirmed her pregnancy. Because of risk of severe bleeding and complexity of the disease, they (Couple) decided to continue the pregnancy. She developed severe per vaginal bleeding at her 12 weeks of gestation and admitted at DMCH for splenectomy operation .She was duly immunized against pneumococcus, meningococcus. Her active bleeding was stopped after fresh frozen plasma transfusion and sonography revealed that single viable pregnancy of 13weeks size, moderate amount of retro placental collection and no splenomegaly. Her splenectomy operation was postponed and pregnancy was continued uneventfully till term. Her anomaly scan was done at 24 weeks of gestation \& revealed no fetal anomaly.

After admission in the hospital, she was followed up for one week. Clinically she was well. There were few purpuric spots, especially in the legs. Her all test reports and USG of pregnancy profile was normal except total platelet count (TPC), which was less than $10000 / \mu \mathrm{L}$ of blood. Her TPC rose to $50,000 / \mu \mathrm{L}$ by allowing complete bed rest and reducing physical activity in addition to Prednisolone. After consultation with hematologist her pregnancy was terminated by elective caesarean section. She was transfused four units of platelet before caesarean section and caesarean delivery was performed within one hour after transfusion. Her platelet transfusion continued for three consecutive days ${ }^{3}$ in the same way and start Danazol (100mg) orally from the first post operative day. Her intra-operative and post operative period was uneventful. She delivered a male baby weighted 2.5 kg, APGAR score 8/10 and 10/10 .Immediately after delivery baby was seen by Pediatrician and found healthy. Breast feeding established successfully. She was discharged on seventh post operative day with platelet count was $20000 / \mu \mathrm{L}$ and platelet count rises $400000 / \mu \mathrm{L}$ after seven days.

\section{Discussion:}

Pregnant women with ITP can be asymptomatic or may present with a history of easy bruisability, bleeding into the mucous membranes (epistaxis or gingival bleeding), or purpura ${ }^{3,4,5}$ ITP occurs in all races ${ }^{1}$ and is diagnosed more commonly in females than males (ratio 3:1) ${ }^{1,2,4-}$ ${ }^{6}$, specially in women of child bearing age $\left(2^{\text {nd }}\right.$ and $3^{\text {rd }}$ decade of life $)^{1,4,5}$ with an incidence of one to two in 1000 pregnancies ${ }^{7,8}$ They may have a history of menorrhagia or menometrorrhagia prior to pregnancy, history of delivering a term newborn with thrombocytopenia, visceral or intracranial hemorrhage, or spontaneous or prolonged bleeding after venipuncture 4. Most women with ITP have normal findings on physical examination (splenomegaly is absent) and purpura may be present especially in the lower limb ${ }^{4,7}$. Newborns have normal findings on physical examinations, no cephalohematoma, ecchymoses over the presenting part, and no purpura ${ }^{4}$.

ITP is a diagnosis of exclusion with peripheral thrombocytopenia and normal or increased megakaryocytes in the bone marrow , red and white cell count is normal ${ }^{1,2,4}$.There is no history of drug intake (e g, heparin, sulfonamides), Gestational thrombocytopenia, Preeclampsia in current pregnancy, and other medical conditions that can cause thrombocytopenia (e g, leukemia, viral infection) ${ }^{4}$. Platelet counts less than $70,000 / \mu \mathrm{L}$ are suspicious for the disorder ${ }^{1}$. Bone marrow aspiration demonstrates normal or increased numbers of megakaryocyte ${ }^{4}$.Anti platelet antibodies can be detected in the serum of women with ITP. A negative test does not exclude the diagnosis ${ }^{1,4,5,7}$. Additionally, many women with gestational thrombocytopenia have high levels of circulating platelet-associated immunoglobulin. ${ }^{1}$

\section{References:}

1. Jamaes N George, Muzahid A. Rizvi: Thrombocytopenia: Ernest Beutler Marshall A Lichtman, Barry S Coller Thonmas J Kipps,Uri Seligsohn: Williams Hematology: McGraw-Hill, New York, $6^{\text {th }}$ edition:2001. Pp 1514-1520.

2. Giles C, Inglis TCM: Thrombocytopenia and macrothrombocytosis in gestational hypertension. Br J Obstet Gynaecol: 1981; 88:1115.

3. Carr JM, Kruskall MS, Kaye JA, Robinson SH: Efficacy of platelet transfusions in immune thrombocytopenia. Am J Med 80:1051, 1986.

4. Frank Firkin, Colin Chesterman, David Penington\& Bryan Rush: de Gruchy's Clinical Haematology in Medical Practice. The Hemorrhagic Disorder: Capillary and Platelet defects; ch14, 5thedition, Blackwell Science, pp 377-385. 
5. Robert N Handin, Clotting disorders; Harrison Principle of Medicine ; McGraw-Hill, New York, 13th edition 1994, vol 2, pp1800.

6. George JN, EI-Harake MA, Raskob GE: Chronic idiopathic thrombocytopenic purpura. N Eng J Med 1994;331:1207.

7. Lynnae millar, MD; Immune Thrombocytopenia and Pregnancy, Last Updated: June 29, 2006.

8. Keith, Edmonds: Disorders of platelets in pregnancy: Dewhurst's Textbook of Obstetric and Gynaecology for post graduates; $6^{\text {th }}$ edi: Blackwell Science Page 229-233.

9. George JN, Woolf SH,Raskob GE, et al: Idiopathic thrombocytopenic purpura:A practical guideline developed by explicit methods for the American society of hematology, Blood 88:3,1996.
10. kitchens CS, Pendergast JF: Human thrombocytopenia is associated withstructural abnormalities of the endothelium that are ameliorated by glucocorticosteroid administration. Blood 67:203, 1986.

11. Gernsheimer T,Stratton J,Ballem PJ,Slicher SJ: Mechanism of response to treatment in autoimmune thrombocytopenic purpura. N Eng J Med ; 1989;320:974.

12. Bussel JB: Immune thrombocytopenia in pregnancy: autoimmune and alloimmune. J Reprod Immunol 1997 Dec 15; 37(1): 35-61[Medline].

13. Jobaida Sultana, Kohinoor Begum,Masuma Jalil,Md.Monir Hossain Khan; Immune thrombocytopenic purpura and pregnancy: a case report: Bangladesh J Obstet Gynecol,2006, 21(2):90-92. 